\title{
JOURNAL OF AFRICAN LAW
}

Vol. XIV

Spring 1970

No. $\mathbf{I}$

\section{NOTES AND NEWS}

\section{The Future of Legal Education in Uganda}

The Uganda government has recently issued the report of a committee appointed to advise on legal education, together with its own memorandum setting out government proposals thereon. 1 The document makes very interesting reading. It is not possible to summarise in a short note the views and recommendations of the committee, which consisted of Mr. Commissioner L. C. B. Gower of the United Kingdom Law Commission, Professor Quintin Johnstone, then Dean of the Faculty of Law in Addis Ababa, and Professor R. B. Stevens, of Yale University; it suffices to say that the government expresses its general agreement with their Report and its recommendations, though there were one or two detailed recommendations where the government has taken a different line, notably in favouring the continuation of physical separation between the Law Development Centre and Makerere University College, in rejecting the proposal that the University should control the Centre, in preferring a three-year to a four-year course for the LL.B., and the further proposal of the committee that there should be a delay of one year between obtaining the local law degree and enrolling for the postgraduate course at the Centre. The government does not accept that the Council of Legal Education should be merged with the Management Committee of the Law Development Centre. The government proposes to change the designation of practising lawyer in Uganda from "advocate" to "attorney", as more appropriate to a fused profession.

The Uganda government is to be congratulated on the care that has been taken to obtain advice on the future of legal education in Uganda, ${ }^{2}$ and on the promptitude with which this report and memorandum have been published. For the convenience of readers, the summary of the government's proposals printed in the document $^{3}$ is given below.

1 Government Memorandum on the Report of a Committee Appointed to Study and make Recommendations Concerning Legal Education, Govt. Printer, Entebbe, Sessional Paper No. 3 of 1969, Shs. 6.

2 Notably from Professor A. N. Allott (University of London), Professor C. Parry (University of Cambridge), Mr. J. S. Bainbridge (International Legal Center); Mr. Justice L. P. Saldanha, and Mrs. M. Rogers (University College, Nairobi).

At pp. 20-22. 


\section{Summary of the Government's Proposals Concerning Legal Education and the Legal Profession}

88. The Government intends to promote the necessary legislation to provide that compulsory attendance at a post-graduate course at the Law Development Centre will come into effect on the ist June, 1970, and that all persons who graduate or are called to the Bar after that date must attend a course at the Law Development Centre and take the pre-enrolment examination. Provision will also be made that persons in practice either as advocates or in Government Service on the ist June 1970 will be exempt from the new provisions, and that persons who are not enrolled but are at present entitled to be enrolled shall be exempt, provided that they become enrolled before the 3 Ist December, 1970. It is envisaged that the first post-graduate course at the Law Development Centre will start in October, 1970.

89. The Government's proposals are set out in some detail in the body of this memorandum, but it may be helpful to those reading this Paper if they are set out briefly here:

(1) Persons desiring to be enrolled as lawyers must obtain a law degree, preferably at Makerere and then undergo a one-year course of practical training at the Law Development Centre, after which they will serve six months' pupillage with a practising lawyer before being enrolled as attorneys.

(2) The Government is hopeful that the degree course will be taught in such a way as to produce graduates with an understanding of law in society and a deep and thorough grounding in legal principles.

(3) Foreign law degrees will be recognised if approved by a reconstituted Council of Legal Education to be known as "The Law Council'". However, if holders of recognised degrees wish to practise law in Uganda they will have to study and be examined in specified subjects and will also be required to undertake the post-graduate course at the Law Development Centre.

(4) Call to the English, Irish and Scottish Bar and other Commonwealth and foreign qualifications will not automatically entitle a person to practise law in Uganda. The Law Council will have power to recognise foreign legal qualifications but the holders will be expected to attend the one year course at the Law Development Centre and serve six months' pupillage. However the Council may exempt such persons from the above requirements if they have practised in their own country for a minimum of five years and their country affords Uganda qualified lawyers reciprocal treatment.

(5) The same rules will apply to solicitors from England, Ireland or Scotland.

(6) There will be certain transitional provisions enabling those persons now studying for the Bar examinations to be accepted as eligible for entry to post-graduate courses at the Law Development Gentre.

(7) Those persons who are qualified to practise law in Uganda 
who are in practice either as advocates or in Government Service on the Ist June, 1970 will be exempted from the new provisions. Persons qualified to practise on that date but who are not in practice will be entitled to be enrolled provided they make application before the 3 Ist December, 1970 .

(8) The Law Development Centre will remain in its present accommodation and the Government proposes that the Centre shall be incorporated by an Act of Parliament.

(9) The Government will support the creation of a Law Faculty at Makerere in place of the present Department of Law.

(10) The Government will undertake a study into the financial rewards open to teachers of law in order to see whether steps can be taken to improve prospects open to them so that persons of the highest calibre, including successful practitioners, may be attracted to a teaching career.

(I I) The Government is carrying out a study of the legal aid system in Uganda, with a view to an expansion and reorganisation of the system under the auspices of the Law Council.

(12) The Council of Legal Education will be re-constituted and renamed "The Law Council". It will be responsible for legal education; professional ethics; deciding on what foreign law degrees will be recognised in Uganda and what extra subjects holders of those degrees will require to be examined before admission to the Law Development Centre; the appointment of an examinations board to assess the performance of students at the Law Development Centre; discipline of the profession and any other matters concerning the Legal Profession referred to it by the Attorney-General.

(13) Persons seeking appointment as lay magistrates will be required to undergo a pre-appointment course at the Law Development Centre, their appointment being conditional upon successful completion of the course. The method of selection of candidates for appointment is to be revised to ensure that only the best candidates are selected.

(14) Newly-appointed magistrates will serve a six-months' apprenticeship with experienced magistrates.

(I5) The Government will announce its decision with regard to a revised salary scale for members of the Judiciary as soon as this has been made.

(16) The Grade III magistrates will be gradually phased out and Grade II magistrates' posts will be gradually staffed by qualified lawyers by means of encouraging present incumbents to qualify and encouraging young, newly-qualified lawyers to seek a career on the bench.

(I 7) A public officer is to be appointed who will be responsible for the smooth operation of magistrates' courts and for dealing with complaints about the courts from members of the public.

(18) The Law Development Centre will run courses for administrative officers and military and police personnel.

The Law Development Centre will assist the Law Reform Committee in its work; will operate a research department; carry out law reporting and publish a legal periodical. 
The Law Development Centre will also assist the legal profession by keeping it abreast of developments in the law and running refresher courses and courses in specialist subjects, and seminars.

(19) The fee for enrolment for newly-qualified lawyers will be reduced from Shs. $4^{\text {oo }}$ to Shs. $4^{\circ}$.

(20) The court dress for advocates is to be changed. All advocates will wear a dark suit with a white shirt and a black tie, together with a gown of local design and manufacture. It will not be compulsory for wigs to be worn by lawyers.

(21) The rules with regard to professional conduct of lawyers are to be revised and lawyers' clerks are to be made subject to professional discipline.

(22) The accounts rules are to receive particular attention and lawyers will not receive their annual practising certificates unless they can produce a certificate from an approved accountant certifying that they have complied with the accounts rules.

(23) The Government is to carry out an investigation into lawyers' costs so that rules may be drawn up to protect the public from over-charging and, if it is possible, enable prospective clients to know what a lawyer's services will cost.

(24) The machinery for disciplining lawyers is to be revised and streamlined. Complainants will petition a committee of the Law Council with powers to remove a lawyer, suspend him from practice or fine him and, where applicable, order him to pay reparation; and there will be a right of appeal to a special bench of the High Court. The Committee will also hear complaints against lawyers' clerks.

(25) Practising lawyers will be renamed attorneys.

(26) Compulsory membership of the Law Society is to be discontinued. 